\title{
Pengambilan Keputusan Dalam Penerimaan Karyawan Bank Dengan Pendekatan Terstruktur Berbasis Sistem Pakar
}

\author{
N. Tri Suswanto Saptadi ${ }^{1}$ \\ ntsaptadi@yahoo.com
}

\author{
Vini Silviani Sebukita ${ }^{2}$ \\ vini_sebukit4@yahoo.com
}

\begin{abstract}
Development of the information services in recruitment bank employees cannot be supported the availability of the information system component. Meeting the need of the availability of good and competence employees needs to key attention to the recruitment and placement of the employees effectively. The use of expert system in recruitment helps the decision making contribute to the placement of the employees. This effort greatly assists personnel managers in making decisions in a way to minimize the positioning error and to know the characteristics of prospective employees of the bank. The research method begins by collecting facts through interviews and questionnaires. Stages followed by analysis of the problem to get answers. To connect the user to use an expert systems with a system modeling. Development in the addition of applied knowledge through system programming. Application of the system to help managers in making decisions on personnel recruitment.
\end{abstract}

Keywords: recruitment, expert systems and decision making.

\section{LATAR BELAKANG}

\subsection{Pendahuluan}

Bank adalah suatu industri yang bergerak di bidang kepercayaan, yang dalam hal ini adalah sebagai Financial Intermediary atau media perantara keuangan antara debitur dan kreditur dana (Santoso, 1997). Menurut UU No. 14 tahun 1967 tentang Pokok-pokok Perbankan, pada pasal 1 disebutkan bahwa bank merupakan lembaga keuangan yang usaha pokoknya adalah memberikan kredit dan jasa dalam lalu-lintas pembayaran dan peredaran uang. Kehidupan bisnis dalam perbankan sarat akan peluang, kesalahan dan kompetisi. Untuk menjawab fenomena dan meningkatkan kualitas layanan diperlukan ketersediaan sumber daya manusia yang memadai. Melalui upaya perwujudan situasi demikian perlu peningkatan kesadaran tentang maksud dari semua kegiatan manajemen sumber daya manusia, yaitu untuk meningkatkan sumbangan sumber daya manusia terhadap keberhasilan organisasional (Siagian, 2002).

\footnotetext{
${ }^{1}$ Jurusan Teknik Informatika, Fakultas Teknologi Informasi, Universitas Atma Jaya Makassar.

${ }^{2}$ Jurusan Teknik Informatika, Fakultas Teknologi Informasi, Universitas Atma Jaya Makassar.
} 
Peningkatan pelayanan informasi dalam proses penerimaan karyawan mengacu akan ketersediaan komponen sistem informasi (Kadir, 2003). Perencanaan yang baik dan matang perlu memperhatikan proses bisnis yang terjadi. Pada pelaksanaannya, bank melakukan tes karyawan melalui beberapa proses, yaitu: Proses seleksi berkas, interview awal, test paper (tes tertulis) dan test ability secara online (test online), interview akhir, dan medical test. Proses test paper melalui beberapa tes dalam bentuk lain seperti tes psikologi dan tes pengetahuan. Masalah yang sering terjadi pada penentuan posisi karyawan dikarenakan kurang obyektifitas dalam proses pengambilan keputusan. Pengunaan sistem pakar dalam proses ini diharapkan dapat membantu untuk mempermudah pengambilan keputusan. Sistem pakar akan memberi bobot untuk menentukan karakter dan posisi karyawan sehingga dapat meminimalisir terjadinya beberapa kesalahan. Upaya menentukan posisi dan mengetahui karakter calon karyawan yang dilakukan oleh manager personalia dapat membantu pengambilan keputusan. Penelitian dilakukan dalam upaya untuk membangun suatu sistem yang relevan dan akomodatif.

\subsection{Permasalahan}

Apakah hasil tes penerimaan karyawan bank dalam bentuk informasi karakter dan posisi dengan pendekatan terstruktur berbasis sistem pakar dapat membantu bagian personalia dalam mengambil keputusan?

\section{LANDASAN TEORI}

\subsection{Emotional Quotient (EQ)}

Kecerdasan emosional adalah kemampuan seseorang mengatur kehidupan emosinya dengan inteligensi (to manage our emotional life with intelligence), menjaga keselarasan emosi dan pengungkapannya (the appropriateness of emotion and its expression) melalui keterampilan kesadaran diri, pengendalian diri, motivasi diri, empati dan keterampilan sosial (Goleman, 2004). Penentuan tes EQ pada kecerdasan emosional untuk memotivasi diri dibagi menjadi empat kategori Tes, yaitu: eksovert, kejujuran, tanggung jawab dan ketenangan sikap (Sunar D., 2010).

\subsection{Komponen Sistem Informasi}

Pada sistem informasi terdapat proses yang diselenggarakan untuk mendapatkan informasi melalui suatu prosedur yang memanfaatkan sumber daya manajemen ke dalam suatu keperluan tertentu (Siagian, 2002). Pemanfaatan sumber daya informasi memerlukan ketersediaan komponen sistem informasi, yaitu: perangkat keras (hardware), perangkat 
lunak (software), prosedur, manusia (user), basis data (database) serta jaringan komputer dan komunikasi data (Kadir, 2003).

\subsection{Pengertian dan Konsep Dasar Sistem Pakar}

Sistem pakar merupakan salah satu cabang dari AI (Artificial Intelegence) yang membuat penggunaan secara luas knowledge yang khusus untuk penyelesaian masalah tingkat manusia yang pakar. Seorang pakar adalah orang yang mempunyai knowledge atau kemampuan khusus yang orang lain tidak mengetahui atau mampu dalam bidang yang dimilikinya. Sistem Pakar adalah sistem perangkat lunak komputer yang menggunakan ilmu, fakta, dan teknik berpikir dalam pengambilan keputusan untuk menyelesaikan masalah-masalah yang biasanya hanya dapat diselesaikan oleh tenaga ahli dalam bidang yang bersangkutan (Marimin, 1992). Sistem pakar adalah sistem yang berusaha mengadopsi pengetahuan seorang ke komputer agar komputer dapat menyelesaikan masalah seperti yang biasa dilakukan oleh para ahli (Kusumadewi, 2003). Tujuan dari sebuah sistem pakar adalah untuk mentransfer kepakaran yang dimiliki seorang pakar kedalam komputer, dan kemudian kepada orang lain/nonexpert (Arhami, 2004). Sistem pakar memiliki ciri-ciri, yaitu: memiliki fasilitas informasi yang handal, mudah dimodifikasi, dapat digunakan dalam berbagai jenis komputer dan memiliki kemampuan untuk belajar beradaptasi. Pakar memiliki kemampuan untuk menganalisis dan meningkatkan kinerjanya. Kemampuan tersebut adalah penting dalam pembelajaran terkomputerisasi, sehingga program akan mampu menganalisis penyebab kesuksesan dan kegagalan yang dialaminya (Turban, 2003).

Konsep dasar dari suatu sistem pakar mengandung beberapa unsur/elemen, yaitu keahlian, ahli, pengalihan keahlian, inferensi, aturan, dan kemampuan menjelaskan. (Turban, 1995). Terdapat tiga orang yang terlibat dalam sistem pakar, yaitu:

a. Pakar adalah orang yang memiliki kemampuan khusus, pendapat, pengalaman dan metode, serta kemampuan untuk mengaplikasikan keahliannya tersebut guna menyelesaikan masalah.

b. Knowledge engineer (perekayasa sistem) adalah orang yang membantu pakar dalam menyusun area permasalahan dengan menginterpretasikan dan mengintegrasikan jawaban-jawaban pakar atas pertanyaan yang di ajukan mengambarkan analogi, mengajukan counter example dan menerangkan kesulitan-kesulitan konseptual.

c. Pemakai yang terdiri dari: pemakai bukan pakar, karyawan, pembangun sistem pakar yang ingin meningkatkan dan menambah basis pengetahuan serta pakar.

\subsection{Komponen Sistem Pakar}

Menurut Siswanto (2005) komponen yang ada pada sistem pakar terdiri dari: 
a. Basis Pengetahuan (Knowledge Base): merupakan inti dari suatu sistem pakar, yaitu berupa representasi pengetahuan dari seorang pakar. Basis pengetahuan tersusun atas fakta-fakta dan kaidah. Fakta adalah informasi tentang objek, pariwisata atau situasi. Sedangkan kaidah merupakan cara untuk membangkitkan suatu fakta baru dari faktafakta yang sudah diketahui.

b. Antar Muka Pemakai (User Interface): bagian dari sistem pakar yang digunakan sebagai alat komunikasi antara pemakai (user) dengan komputer. Terdapat dua tipe pengguna interface di dalam sistem pakar yaitu: Knowledge Engineer dan Pemakai (User).

c. Mesin Inferensi (Inference Engine): bagian yang mengandung mekanisme fungsi berpikir dan pola-pola sistem yang digunakan oleh seorang pakar. Mekanisme ini akan menganalisa suatu masalah tertentu dan selanjutnya akan mencari jawaban atau kesimpulan yang terbaik. Mesin inferensi merupakan komponen dari sistem pakar yang berfungsi sebagai mesin pengambil keputusan berdasarkan fakta yang ada pada basis pengetahuan sistem pakar. Secara deduktif mesin inferensi memilih pengetahuan yang relevan dalam rangka mencari kesimpulan.

d. Mesin Pengembangan (Development Engine): Bagian dari pakar sebagai fasilitas untuk mengembangkan mesin inferensi dan penambahan basis pengetahuan yang akan dilakukan oleh knowledge engineer.

Metode Pelacakan atau Penalaran merupakan metode untuk mengambil suatu kesimpulan atau keputusan. Terdapat 3 (tiga) metode yaitu: Forward Chaining, Backward Chaining dan Rule-Value. Metode Pencarian (Searching) memiliki beberapa teknik inferensi yang biasa digunakan, yaitu:

a. Depth First Search (DFS) adalah teknik penelusuran data pada node-node secara vertical dan sudah didefinisikan.

b. Breadth First Search: adalah Teknik penelusuran data pada semua node dalam satu level atau satu tingkatan sebelum ke level atau tingkatan di bawahnya.

c. Best First Search: bekerja berdasarkan kombinasi dari depth first search dan breadth first search. Metode ini pada dasarnya adalah metode pencarian dengan mengacu pada goal terbaik.

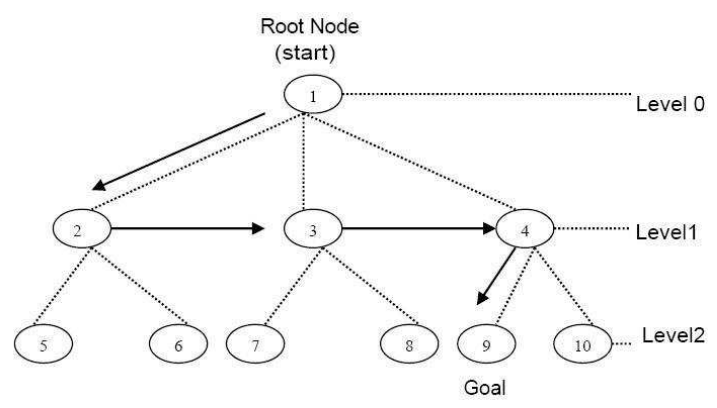

Gambar 1. Pencarian Best First Search 
Best First Search bekerja berdasarkan kombinasi dari depth first search dan breadth first search. Metode ini pada dasarnya adalah metode pencarian dengan mengacu pada goal terbaik. Sehingga proses pencarian menjadi lebih cepat dibandingkan dengan metode pencarian yang lainnya.

\subsection{Pengambilan Keputusan}

Pengambilan keputusan didasari pada fakta dan data yang telah dikumpulkan. Data yang telah terkumpul tersebut akan diubah menjadi suatu informasi. Data inilah yang akan menjadi dasar dalam proses pengambilan keputusan (Saptadi, 2011).

\section{Metode Penelitian}

Perancangan sistem dimulai dengan cara menentukan tiga orang yang terlibat dalam sistem pakar (Turban, 1995), yaitu psikiater sebagai pakar, kepala wilayah dan kepala bagian sebagai knowledge engineer dan HRD sebagai pemakai. Pendekatan yang digunakan adalah terstruktur dengan mengikuti tahapan siklus hidup pengembangan sistem dengan dilengkapi alat dan teknik yang dibutuhkan dalam pengembangan sistem, sehingga hasil akhir dari sistem yang dikembangkan akan diperoleh hasil sistem terstruktur yang didefinisikan dengan baik dan jelas. Metode penelitian dimulai dengan cara mengumpulkan fakta-fakta melalui wawancara dan kuesioner. Tahapan dilanjutkan dengan analisa masalah hingga memperoleh jawaban. Metode pelacaran dan penalaran menggunakan Forward Chaining dan teknik inferensi dalam pemecahan masalah menggunakan Best First Search. Untuk menghubungkan antara sistem pakar dengan pengguna digunakan pemodelan sistem berupa data flow diagram, data dictionary dan flowchart. Pengembangan dalam penambahan pengetahuan diterapkan melalui pemrograman sistem. Peralatan perangkat lunak menggunakan bahasa pemrograman PHP dengan Apache Web Server dan database Server MySQL (Kadir, 2009). Untuk pemodelan menggunakan Visio, Dbdesigner dan Macromedia Dreamweaver.

\section{Hasil dan Pembahasan}

\subsection{Hasil Pengumpulan Data Pengetahuan}

Pengumpulan data dilakukan melalui wawancara dan kuesioner. Jumlah responden adalah 10 orang yang terdiri dari 1 orang kepala wilayah, 2 orang kepala bagian lainnya, 6 orang HRD bank, dan 1 orang psikiater. Pelaksanaan wawancara dan kuesioner terhadap responden menghasilkan $90 \%$ orang melakukan tes masih menggunakan tes secara manual, $80 \%$ calon pelamar merasa proses penerimaan secara manual menghabiskan waktu cukup 
lama, $60 \%$ calon pelamar mengeluh sering terjadi kesalahan dalam menentukan posisi jabatan dan rata-rata orang tidak pernah mendapatkan penjelasan tentang kesalahan dari hasil tes. Hasil lain berupa usulan mengenai fasilitas tambahan aplikasi ini, yaitu: berita seputar informasi, profil dan contact person bank.

\subsection{Pembentukan Mesin Inferensi}

Pengumpulan data menghasilkan fakta dengan rincian 4 buah kategori, 3 tingkatan pendidikan, 9 macam jabatan. Setiap jabatan memiliki beberapa kategori yang sudah ditentukan oleh psikolog, minimal memiliki 4 sifat berdasarkan setiap jabatan yang ada. Setiap kategori memiliki 5 pertanyaan dengan masing-masing terdapat 4 pilihan. Pada setiap pilihan memiliki pembobotan dengan skala bervariasi dari 1 hingga 10. Terdapat 13 buah kemungkinan hasil yang diperoleh berdasarkan karakter yang dimiliki dan posisi yang diharapkan oleh pelamar yang dihitung dari pembobotan. Hasil penghitungan berupa posisi yang dinilai, posisi yang memenuhi dengan lamaran, jabatan yang sesuai dan jabatan lain yang memungkinkan. Model konsep sistem pakar yang terbentuk dari analisis, yaitu:

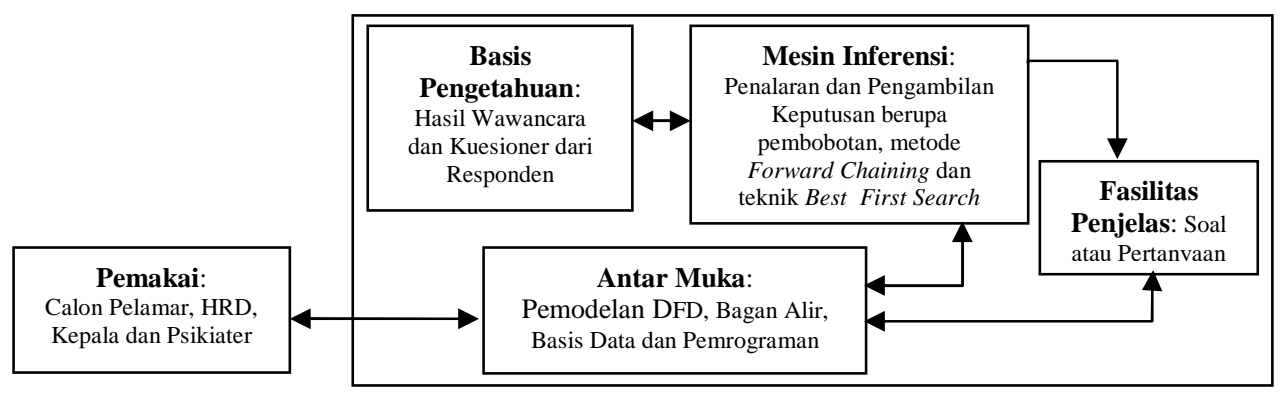

Gambar 2. Model konsep sistem pakar

Aturan yang diciptakan akan mempengaruhi proses. Pengambilan keputusan di mulai dengan mempelajari posisi lamaran yang diinginkan oleh calon pelamar. Posisi yang diinginkan adalah posisi saat mengajukan lamaran oleh calon pelamar sehingga dapat memilih posisi yang dinginkan. Setelah melakukan tes, hasil tes dapat menjelaskan hasil posisi yang memenuhi dengan lamaran. Jika hasil dari saat mengajukan lamaran ada pada posisi yang didapatkan pada hasil tes, calon pelamar akan mendapatkan posisi yang diinginkan. Jika pelamar tidak dapat mendapatkan posisi yang diinginkan sistem pakar dapat memberikan posisi yang lain sesuai dengan hasil tes yang didapatkan atau dapat memiliki posisi yang memungkinkan pelamar bisa memiliki posisi yang sesuai dari hasil tes. 


\subsection{Pemodelan Diagram Arus Data}

Untuk memodelkan sistem yang dirancang, ditentukan dengan memberi nama entitas dan keterkaitan dalam proses yang dilakukan pada sistem pakar.

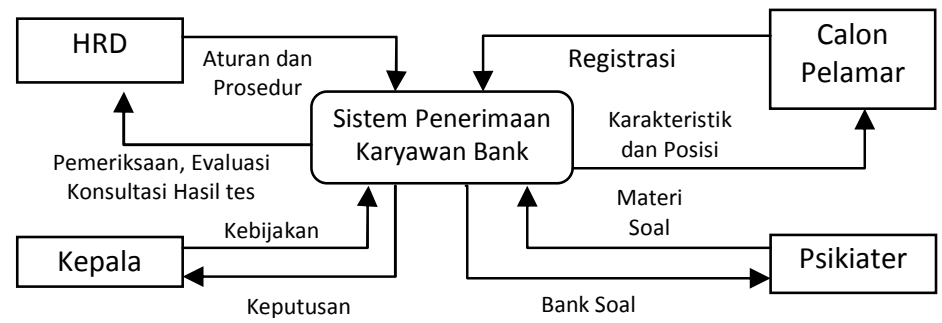

Gambar 3. Diagram konteks

Untuk menjelaskan hubungan proses utama sistem yang ada, dibuatlah diagram level yang menggambarkan keterkaitan antara entitas, proses, aliran dan penyimpanan data.

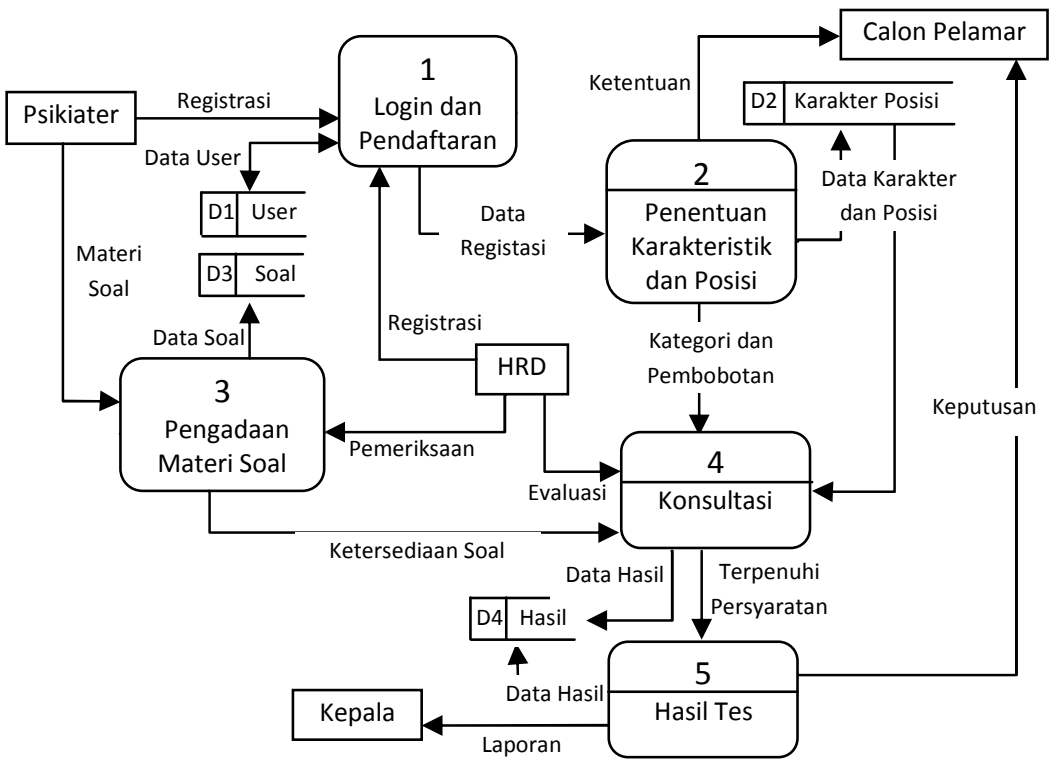

Gambar 4. Diagram level 1

Gambar 4 menunjukkan proses login dan registrasi, karakteristik dan posisi, pengadaan soal, konsultasi dan hasil tes. Hasil proses disimpan pada media penyimpanan dengan nama user, karakter posisi, soal dan hasil berdasarkan aliran data.

\subsection{Pemodelan Bagan Alir}

Pada pembuatan program diperlukan bagan alir agar logika berpikir menjadi efektif. Sebagai contoh digambarkan diagram alir pada tes dan proses soal 

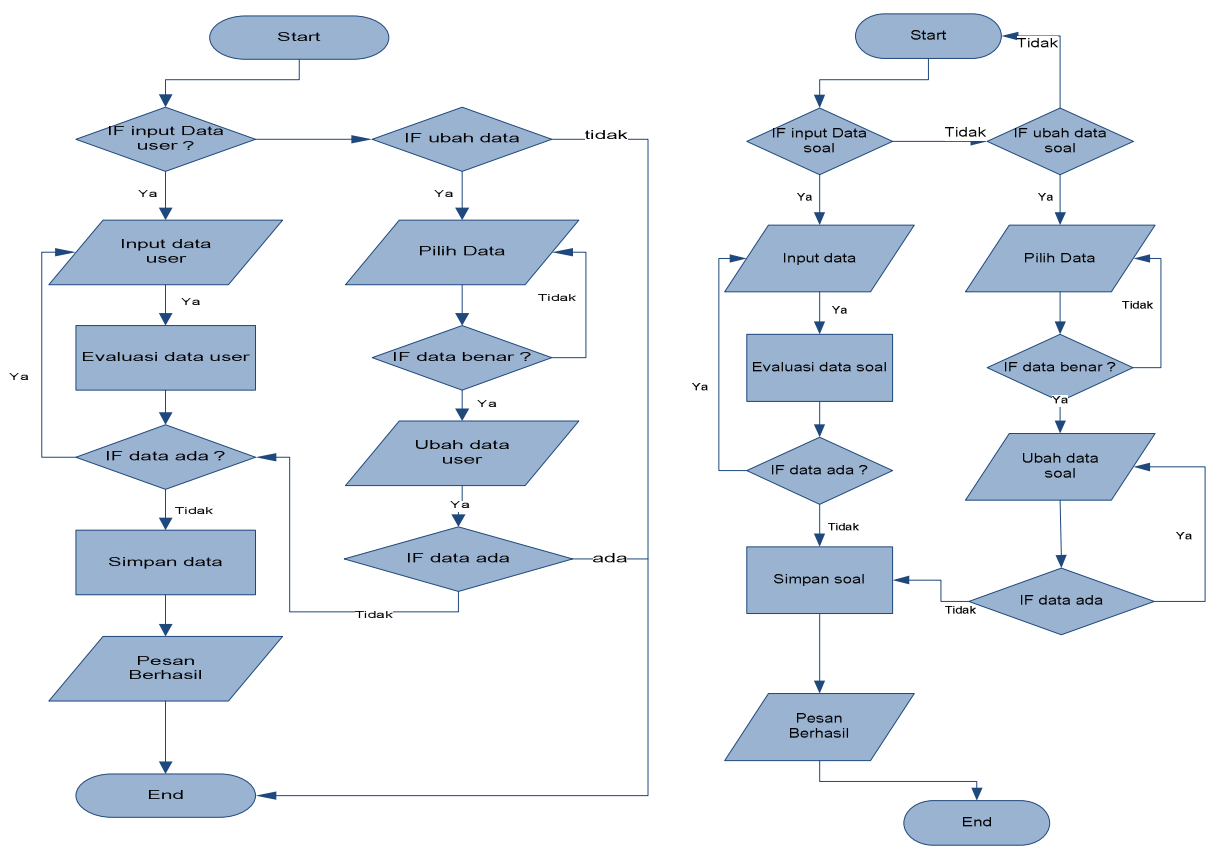

Gambar 5. Diagram alir proses tes
Gambar 6. Diagram alir proses soal

Tahapan berikut adalah pembuatan sistem yang dilakukan dengan menggunakan bahasa pemrograman PHP. Pada tabel 1 menunjukkan contoh kutipan script program hasil tes.

Tabel 1. Kutipan script program hasil tes

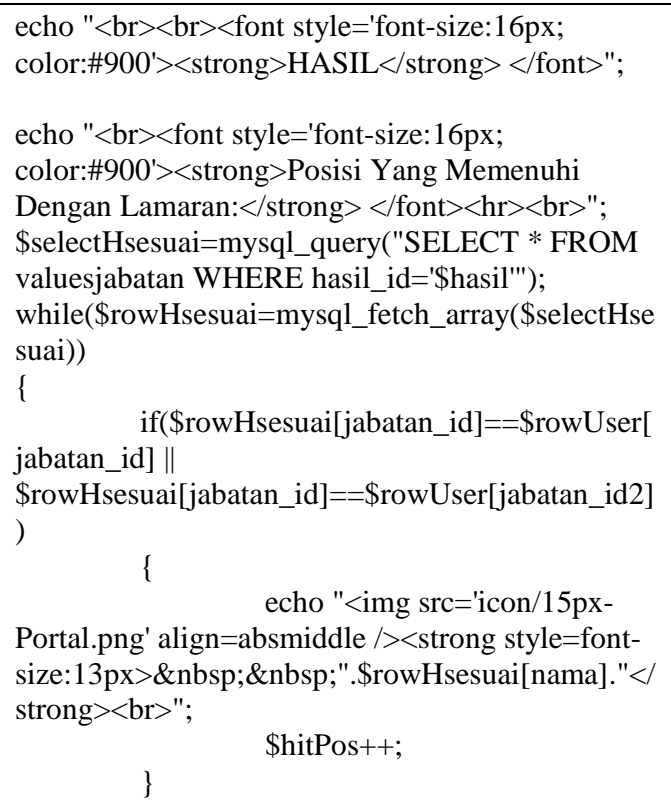

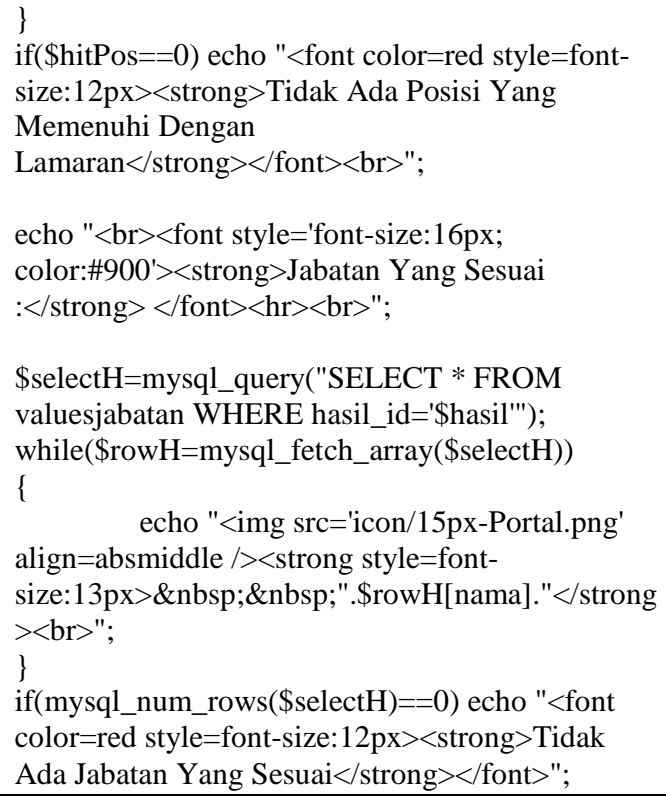

\subsection{Pemodelan Basis Data}

Hasil perancangan aliran data dan logika pemrograman disimpan pada basis data penyimpanan di MySQL dengan editor browser yang diakses melalui phpmyadmin. Berikut salah satu yang dihasilkan yaitu tabel soal. 
Tabel 2.

Struktur tabel soal

\begin{tabular}{|c|c|c|c|c|c|c|c|c|c|c|c|c|c|c|}
\hline & Field & Jenis & Penyortiran & Atribut & Kosong & Default & Ekstra & \multicolumn{7}{|c|}{ Aksi } \\
\hline$\square$ & soal id & $\operatorname{int}(11)$ & & & Tidak & & auto_increment & 整 & $?$ & $x$ & $\pi$ & [u & 3 & $T$ \\
\hline$\square$ & category_id & $\operatorname{int}(11)$ & & & Tidak & & & 7 & $\vartheta$ & $x$ & 78 & [u & 8 & $T$ \\
\hline ㅁ & nama & tinytext & latin1_general_ci & & $\mathrm{Ya}$ & NULL & & 7 & 8 & $x$ & $\pi$ & Tu & 3 & $\pi$ \\
\hline$\square$ & pila & tinytext & latin1_general_ci & & Ya & NULL & & 7 & $P$ & $x$ & $\pi$ & एบ & 3 & $\pi$ \\
\hline ㅁ & pilb & tinytext & latin1_general_ci & & $\mathrm{Ya}$ & NULL & & $\mathbf{x}$ & 8 & $x$ & 78 & Tu & B & 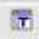 \\
\hline$\square$ & pilc & tinytext & latin1_general_ci & & $\mathrm{Ya}$ & NULL & & 7 & 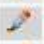 & $x$ & 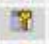 & జี & 8 & T \\
\hline$\square$ & pild & tinytext & latin1_general_ci & & $\mathrm{Ya}$ & NULL & & $\mathbf{x}$ & 2 & $x$ & $x$ & [u & $B$ & $\bar{T}$ \\
\hline$\square$ & pointa & int(11) & & & $\mathrm{Ya}$ & NULL & & T & $z$ & $x$ & $7 i$ & एบ & 3 & $T$ \\
\hline$\square$ & pointb & $\operatorname{int}(11)$ & & & $\mathrm{Ya}$ & NULL & & ㅍ & 8 & $x$ & 7 & [u & 3 & $F$ \\
\hline D & pointc & $\operatorname{int}(11)$ & & & $\mathrm{Ya}$ & NULL & & 7 & 2 & $x$ & 7 & Tu & 3 & $T$ \\
\hline$\square$ & pointd & $\operatorname{int}(11)$ & & & $\mathrm{Ya}$ & NULL & & 電 & 8 & $x$ & 8 & एี & 18 & $T$ \\
\hline
\end{tabular}

Penjelasan Tabel 2 dapat didefinisikan sebagai berikut:

a. Field soal_id merupakan nilai id yang diset sebagai primary key pada tabel soal

b. Field category_id merupakan nilai id yang diset sebagai foreign key pada tabel soal

c. Field nama merupakan isi soal

d. Field pila merupakan pilihan jawaban a

e. Field pilb merupakan pilihan jawaban b

f. Field pilc merupakan pilihan jawaban c

g. Field pild merupakan pilihan jawaban d

h. Field pointa merupakan nilai a

i. Field pointb merupakan nilai b

j. Field pointc merupakan nilai c

k. Field pointd merupakan nilai $d$

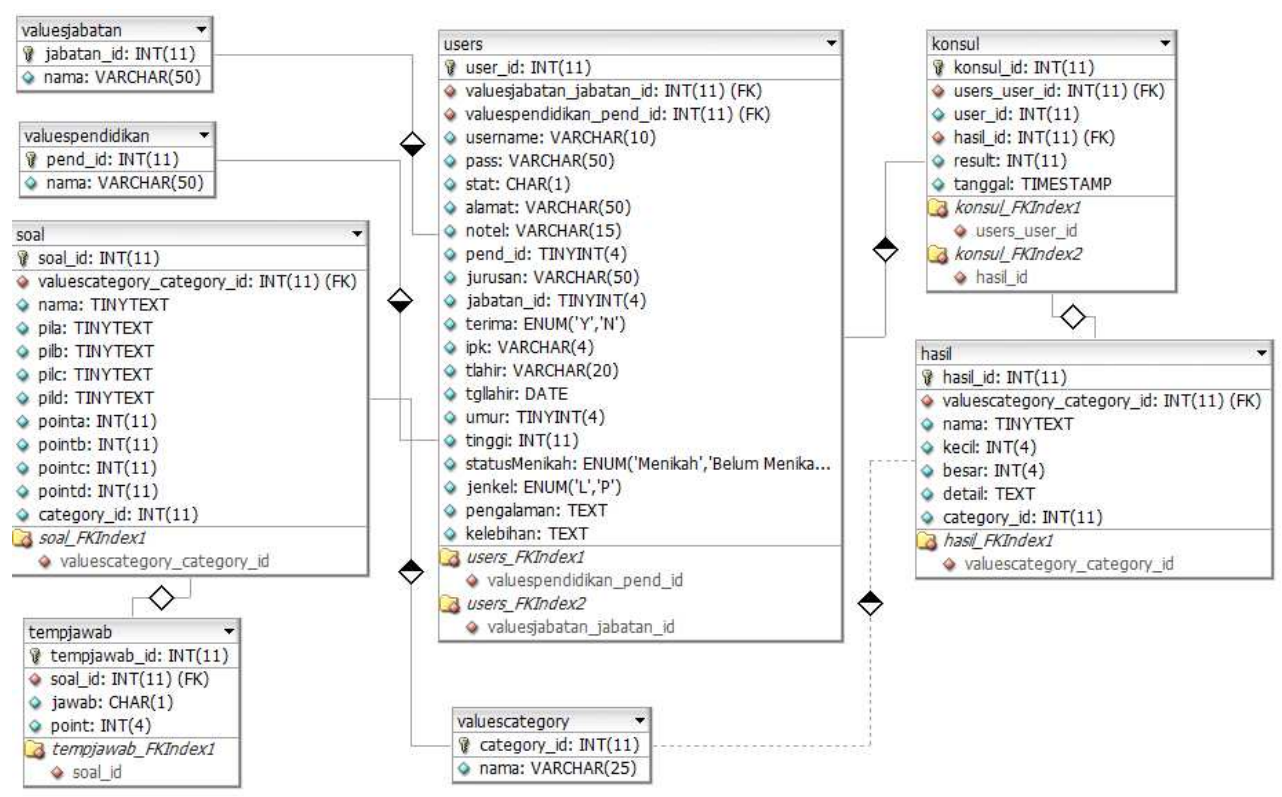

Gambar 7. Entity Relationship Diagram 
Setelah mendefinisikan tabel, kemudian digambarkan hubungan antar tabel dalam bentuk Entity Relationship Diagram (ER-Diagram) seperti tampak pada Gambar 7.

\subsection{Pemodelan Antarmuka}

User interface merupakan bagian dari sistem pakar yang digunakan sebagai media atau alat komunikasi antar user dan sistem. Di dalam user interface ini dibedakan empat user:

a. User umum (Calon pelamar): menggunakan sistem hanya untuk melakukan tes EQ.

b. User pemakai sistem (HRD): melihat hasil tes akhir dan memasukkan data serta mengedit data calon pelamar.

c. User pemakai sistem (Kepala): melihat hasil tes akhir dan menentukan apakah pelamar layak untuk diterima atau tidak sebelum mengambil keputusan hasil akhir tes.

d. User administrator (Psikiater): melakukan proses editing, penambahan user psikiater menggunakan sistem untuk penginputan soal dan pengeditan soal dan dapat melihat hasil tes untuk disimpulkan sebelum pengambilan keputusan.

\subsection{Pengembangan dan Implementasi Sistem}

Setelah dirancang antarmuka, kemudian dibentuk sistem yang dapat diakses melalui browser. Gambar 8 menunjukkan tampilan awal aplikasi dalam sistem pakar.

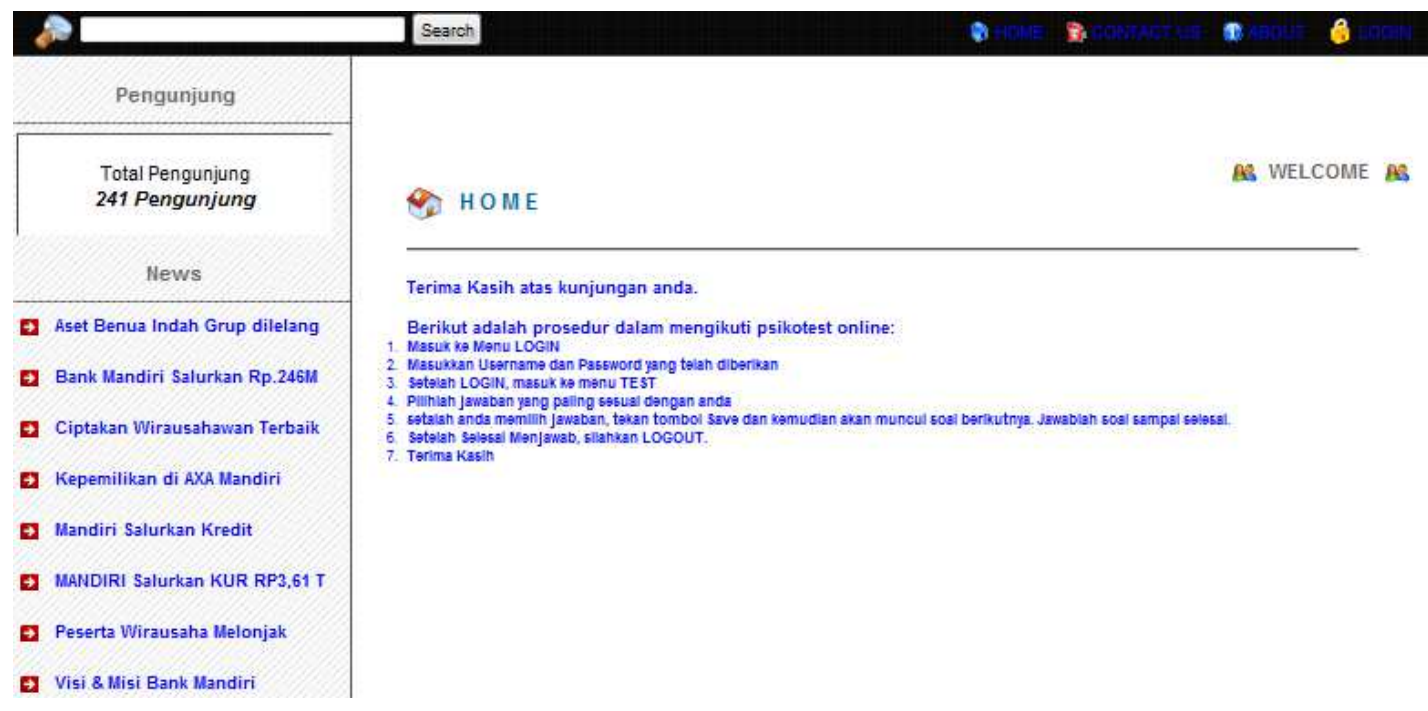

Gambar 8. Aplikasi sistem penerimaan

Untuk menambahkan user perlukan form tambah user dengan isian username, alamat, nomor telpon, pendidikan terakhir, lamaran dan sebagainya. 


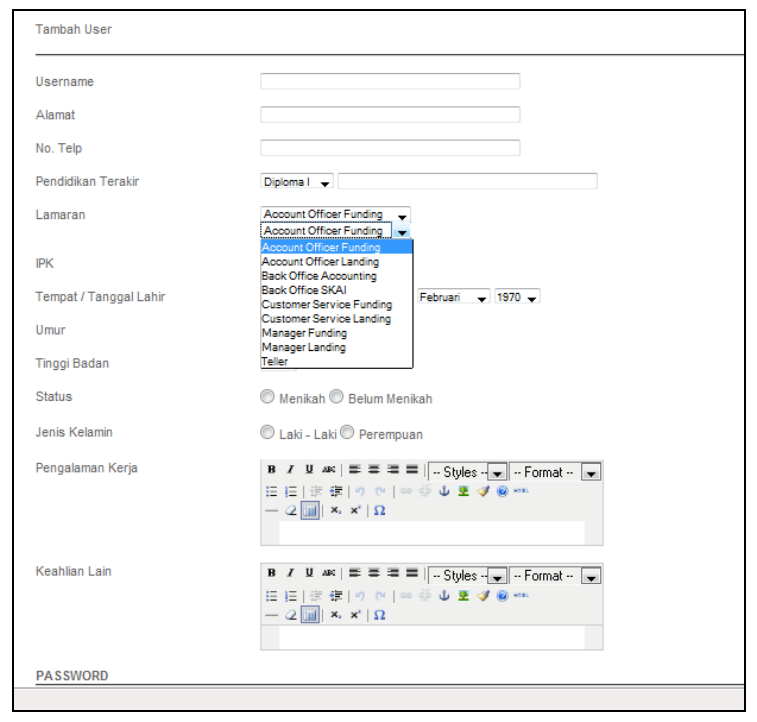

Gambar 9. Tampilan daftar tambah pelamar

Untuk proses menjawab soal dalam tes penerimaan, disediakan form pengisian.

\begin{tabular}{|l|}
\hline PSIKOTEST \\
\hline Tanya Pilihlah salah satu yang paling sesuai dengan anda \\
Jawab○ a. Aku hidup dalam rasa cemas yang menghantui \\
b. Aku jarang memikirkan hal-hal yang tidak penting \\
c. Aku tidak takut sendirian dalam gelap \\
d. Bila mungkin aku akan selalu menghindar dari keramaian \\
S SAVE
\end{tabular}

Gambar 10. Tampilan daftar tampilan soal

Hasil tes berisi karakter yang dimiliki pelamar dapat dilihat pada gambar 11 berikut:

Hasil Test vinwY
Sangat Jujur
Anda adalah orang yang sangat jujur.
Dalam pergaulan di tengah-tengah masyarakat, anda sangat mematuhi atau tunduk pada aturan atau norma yang berlaku di
masyarakat.
Bagi anda, kejujuran ini sangat penting dan merupakan suatu modal utama dalam langkah menuju sukses.
Anda merupakan tipe orang yang bisa selalu jujur dan tidak berbohong
Senang Bergaul
Anda adalah orang yang benar-benar menyenangi pergaulan.
Anda mempunyai banyak kawan, suka mempelajari ilmu pengetahuan, progresif, sedikit urakan, berani tampil dimuka umum,
dan siap memimpin.
beberapa kolega Anda mengatakan bahwa Anda orang yang ambisius dan tak pernah mau mengalah, terutama orang-orang
yang iri pada Anda
Bertanggung Jawab
Tanggung jawab dan semangat kerja anda cukup besar. setiap tugas yang diberikan anda laksanakan dengan baik. anda
biasanya tidak mau mencari pekerjaan yang bukan tugas anda. peraturan yang sesuai dengan anda akan anda ikuti,
sebaliknya yang tidak sesuai dengan anda akan dilanggar.
Dengan sikap tanggung jawab level ini anda sudah bisa menjadi konglomerat dan tokoh-tokoh sukses dalam bisnis dan politik
idola Anda
Dingin dan Sangat Santai
Anda stabil dan yakin dalam menjalani kehidupan. nalar dan pikiran anda memimpin hidup anda. tidak banyak yang anda perlu
bimbangkan karena anda mampu menganalisa dampak positif dan negatif dari setiap perkataan dan perbuatan anda.
anda tidak mudah terserang panik, takut, bisa tegar, dan berdiri tanpa emosi.
banyak yang menganggap anda berdarah dingin. anda biasanya penuh pertimbangan dan mampu berkonsentrasi dengan baik
sehingga hasil pekerjaan anda selalu baik.
anda sangat yakin diri, tidak takut, tidak bimbang, apalagi panik. daya pertimbangan anda cukup baik. berbagai pekerjaan yang
berat dapatanda selesaikan dengan baik.
anda adalah tipe yang cocok sebagai pemimpin karena mampu MEMBACA masa depan dengan sangat baik.

Gambar 11. Tampilan hasil tes karakter 
Posisi berdasarkan hasil tes dapat dilihat pada gambar 12 berikut:

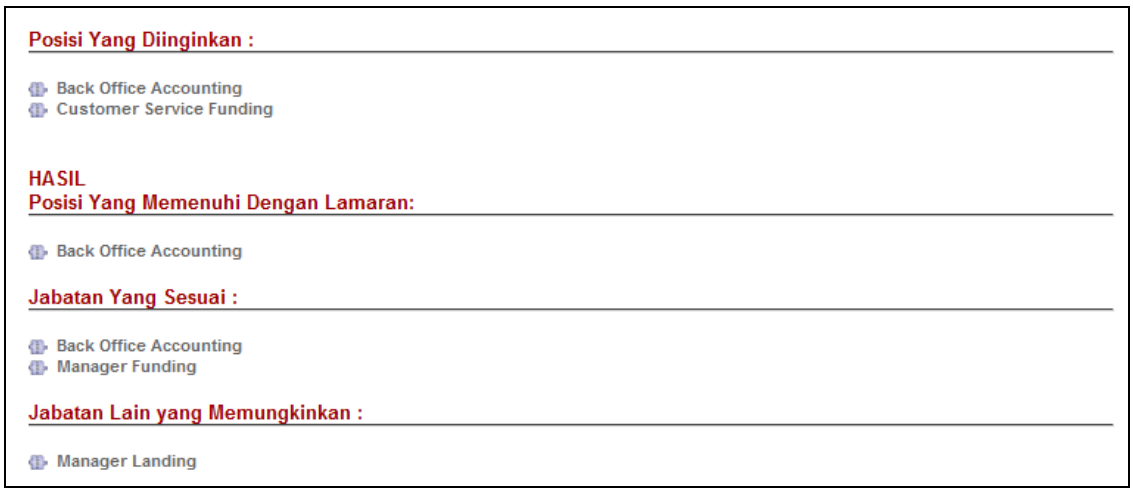

Gambar 12. Tampilan hasil tes posisi

Hasil tes tersebut menjelaskan karakter dari calon pelamar serta hasil posisi apa yang diperoleh setelah melakukan tes. Model tes EQ menggunakan tes yang terbagi menjadi empat kategori yaitu:

1. Tes Eksovert: pribadi eksovert adalah kondisi seseorang dimana dia menyenangi bergaul dan bersama dengan orang lain. Hasil dari tes eksovert memiliki tiga komponen yaitu senang bargaul, tidak senang bergaul dan kompleks memiliki kedua-duanya.

2. Tes Kejujuran: di dalam kehidupan sehari-hari, kita dituntut untuk mematuhi peraturan yang berlaku di masyarakat. Aturan tersebut merupakan moral. Salah satu moral yang dituntut oleh masyarakat adalah jujur dan tidak berbohong.

3. Tes Tanggung jawab: orang bertanggung jawab adalah orang yang secara emosi maupun secara pikiran berani menanggung resiko terhadap pilihan yang telah diambil atau perbuatannya. Hasil dari tes tanggung jawab memiliki tiga komponen yaitu kurang bertanggung jawab, tanggung jawab standar, bertanggung jawab.

4. Tes Ketenangan sikap: pribadi yang peragu merupakan orang-orang yang secara emosi sudah terserang, rasa panik. Hal ini dirasakan oleh orang yang bersangkutan sebagai suatu kondisi di mana terjadi ketakutan yang intens, disertai dengan berbagai gejala somatik, seperti keringat dingin, berdebar-debar, sesak nafas, diare, dan lain sebagainya.

\subsection{Pengambilan Keputusan}

Manajer Personalia dapat melakukan pengambilan keputusan berdasarkan informasi dari sistem. Hasil tes berupa karakteristik dari calon pelamar dapat dijadikan dasar untuk menentukan posisi pekerjaan bagi calon pelamar. Meskipun demikian, jika pelamar tidak dapat memperoleh posisi yang diinginkan, sistem pakar dapat memberikan posisi yang lain sesuai dengan hasil tes yang didapatkan atau juga dapat memiliki posisi yang memungkinkan pelamar bisa memiliki posisi yang sesuai dari hasil tes pelamar. 


\section{Penutup}

Sistem pakar yang telah dibuat menghasilkan aplikasi yang dapat membantu dalam pengambilan keputusan dengan memberikan fleksibilitas dan solusi untuk mengukur kecerdasan emosional yang dapat menentukan karakteristik dan posisi karyawan dari hasil tes. Aplikasi sistem pakar yang telah dirancang diharapkan dapat memudahkan bank mendapatkan karyawan yang berkualitas, bermutu, dan sesuai dengan kebutuhan bank serta dapat mengurangi terjadinya kesalahan dalam menetukan karakter serta posisi karyawan pada penerimaan karyawan.

\section{Daftar Pustaka}

Arhami, M. (2004). Konsep Dasar Sistem Pakar. Yogyakarta: Andi.

Flippo, B. Edwin. (1996). Manajemen Personalia. Jakarta: Erlangga.

Goleman, Daniel. (2004). Emotional Intelligence. Jakarta: PT. Gramedia Pustaka Utama.

Henry, S. (2004). Manajemen Sumber Daya Manusia, Edisi III. Yogyakarta: Unit Penerbitan dan Percetakan Akademi Manajemen Perusahaan YKPN.

Ignizio, J. P. (1991). An Introduction To Expert Systems. Mcgraw-Hill College.

Kadir, Abdul. (2003). Pengenalan Sistem Informasi. Yogyakarta: Andi.

Kadir, Abdul. (2009). Membuat Aplikasi Web dengan PHP dan Database MySQL. Yogyakarta: Andi.

Kusrini. (2008). Aplikasi Sistem Pakar: Menentukan Faktor Kepastian Pengguna dengan Metode Kuantifikasi Pertanyaan. Yogyakarta: Andi.

Kusumadewi, Sri. (2003). Artificial Intelligence: Teknik dan Aplikasinya. Yogyakarta: Graha Ilmu.

Marlinda, Linda. (2004). Sistem Basis Data. Yogyakarta: Andi.

Nugroho, Bunafit. (2008). Membuat Splikasi Sistem Pakar dengan PHP dan Editor Dreamweaver. Yogyakarta: Gavamedia.

Rony, Ainur M. (2011). Sistem Pakar Untuk Mengidentifikasi Kerusakan Kulkas Lg Tipe Gr-S512 Menggunakan Aplikasi Mobile. Malang: Seminar Nasional Teknologi Informasi, Komunikasi dan Aplikasinya (SNATIKA). ISSN 2089-1083. Edisi 11 November.

Santoso, Ruddy. (1997). Mengenal Dunia Perbankan. Yogyakarta: Andi.

Saptadi, Tri Suswanto. (2011). Pengambilan Keputusan Strategis Penggunaan Sistem Informasi dengan Metode Analytical Hierarcy Process. Makassar: Prosiding Konferensi Nasional Forum Teknik Elektro Indonesia (FORTEI). ISBN 978-602-8509-16-9 Edisi 8-9 Desember.

Siagian, Sondang. (2002). Manajemen Sumber Daya Manusia. Jakarta: Bumi Aksara.

Siswanto. (2005). Kecerdasan Tiruan. Yogyakarta: Graha Ilmu.

Sunar, Dwi P. (2010). Edisi Lengkap Tes IQ, EQ dan SQ. Yogyakarta: Flashbooks.

Turban, E. (1995). Decision Support System and Expert System. USA: Prentice Hall International Inc.

Turban, E., dkk, (2003). Decision Support Systems and Intelligent Systems. Jilid 1. Yogyakarta: Andi.

Yuwono, Himatif, Teori Sistem Pakar,

(http://yuwono.himatif.or.id/detail_download.php?aksi=detail\&matakuliah=9/TEORI-SISTEM-PAKAR.doc, diakses 09 Mei 2011).

Yunanto, Wawan, Algoritma Backward Chaining pada Rule-Based Expert System (online), (http://www.pcr.ac.id/wyunanto-backwardchain1.pdf, diakses 19 Oktober 2011). 